www.ccsenet.org/journal.html

\title{
Expression Form of Book Design Art
}

\author{
Yuanyuan Li \\ College of Art and Appareluages, Tianjin Polytechnic University, Tianjin 300160, China \\ E-mail: squirrel0714@gmail.com
}

\begin{abstract}
Books are media for information communication. A nice book design can not only give prominence to the content of book but also construct a rich aesthetic space for readers by its special art language. Therefore, book design should emphasize both exterior beauty and interior beauty. Besides, it should pay attention on the organic unity of book content and book design. Put it in simple, the general configuration of book is three-dimensional and planar. And the exterior shape deserves further creation and innovation. For the sake of properly expressing the real content of book, book design should comprehensively consider the book's covers, space of a whole page, illustrations, nationality style, and the combination of these factors. Finally, unify the book design with the book content to form a unity.

Keywords: Book design, Exterior beauty, Interior beauty, Three-dimensional configuration, Unity of design and content

Books, as the media for information communication, can bring about aesthetic appreciation for people as they transfer knowledge for readers, along with the long development process. Therefore, excellent books possess not only the function of reading materials but also the function of appreciation, collection, communication, and mutual exchange.

Book design is an independent shaping art. Designers have to give prominence to book's content in design on one hand. On the other hand, designers should make best use of art language for book design to construct a rich aesthetic space for readers. By this way, readers can enjoy the essence of the book and gain aesthetic pleasure at the same time. As a result, the content of the book may impress readers' hearts deeply. That is the key of book design. Although book design may use thousands of languages, its object is human being. People's requirements for physical beauty and their requirements for psychological beauty, such as elegance and good taste, do not change a lot. Therefore, researches on book design languages' development and application become new standard for valuating the beauty of book. An excellent book design should have novel and proper expressive form. And its design language should not only reflect but also improve the content of the book in a sense.
\end{abstract}

\section{The beauty of exterior form}

In book design, the general configuration of the book is kind of "shape" design. The book's general configuration includes its size, edition building, paperbacked form, and packaged form. They all reflect the beauty of book's exterior form. The first step of book design is to design book's general shape. The uniqueness of book design firstly means the special exterior configuration of book.

\subsection{The book is three-dimensional.}

Book's beauty in form is not only in face but also in its general configuration. In essence, the art of book design is three-dimensional, multi-lateral, multi-level, and multi-factor. As a matter of fact, books are in a dynamic relationship with readers. Therefore, book's beauty in configuration should be developed in a three-dimensional, multi-lateral, multi-level, and dynamic space.

\subsection{The innovative book form}

Today, many book designers begin to re-shape the form of book, with the hope of changing people's habits and behaviors in reading. By this way, designers can get rid of the bondage of books' fixed mode and advocate imaginable design. In other words, it is to study the aesthetics of books by means of books' design language. Its significance is already beyond books' content and structure. It is to inspire readers' emotions and make them spring out various wisdom. To integrate the books' content and the modern book design is the value of books' configuration reform. In the general design of Heart and Instruction, semi-solid form is employed as its exterior expression. And its design language is enriched with angled line, changing its fixed expression. By this way, its design has realized the innovation of configuration in practice.

\section{The beauty of interior form}

The configuration of book design art means a perfect integration of exterior form and book content. During the process 
of reading, readers should gain static and aesthetic pleasure from every stop and every moment. Therefore, the design of covers and inner pages should be independent and special. It must integrate with not only the solid form of book but also the content of book, achieving the unique charm of book design art.

\subsection{The primary issue is the cover design.}

In book design, the first issue is the design of covers. No matter how covers are designed, it must obey the connotation of a book' spirit, and the general effect of a book, instead of being completely independent. It is impossible for covers to reflect the whole connotation of a book thoroughly. Under the covers, it is the essence of the book, including its pages, illustrations, word styles, and so on. Designers should take all these factors into consideration in order to realize excellent book design. Therefore, designers must arrange these factors reasonably, effectively, and beautifully, making them become a unity and possess their positions respectively. In a sense, the book design is a comprehensive work composed by cover design, illustration art, word style art, and page design. Especially, cover design has key effect on the general configuration of book. As a matter of fact, the design idea, position, language, and form are all necessary parts in cover design.

\subsection{The core is the page design.}

Page design is the core of book design. It deserves more attentions from people.

In recent years, along with the development of books' graphic design, people begin to emphasize the page design. But generally speaking, people's stresses on it are far from sufficiency. The text is the core of a book. What readers care about is nothing but the text. Therefore, the page is design is extremely important. The diversity of page design provides with wider space for designers. Firstly, emphasize the pure and simple style. Secondly, focus on the cultural connotation, aesthetic taste, and humanism carefulness. Thirdly, enhance the concept of general design.

Besides, the words design is irreplaceable in the page design. Different words style will exert different effects on people's emotions and affections, no matter what the effects are subtle or strong. Therefore, the word style should be in accord with the whole style of the book. In order to realize this goal, designers must understand the essence of the book and choose the right word style for the book. By carefully design and arrangement, the word style can help to create wonderful effects on the whole book.

\subsection{The hotspot is the illustration of general design.}

Illustration is the hotspot of general design. As a part of book design, illustration should exert a decorative effect on pages and words. "Illustration" means to make it clear by light. However, to decorate every part with paintings or ornaments is not equal to design or general design. Without a unified aesthetic idea, the general design will not have a soul but a face.

\subsection{The general design should emphasize nationality feature.}

The general design should emphasize the nationality feature, pursuing to reflect its unique nationality style. Each times and nationality has special aesthetic style that is not determined by subjective inclinations but based on its long history and production way. The progresses of economic system and the changes of cultural life habits will inevitably lead to the evolvement of nationality style in book design.

\subsection{The way of combining different factors is important for the general design.}

In book design, the combination of spots, lines, faces, and colors, or the relationship between different combinations are important. For example, contrast or harmony, symmetry or balance, rhythm or repeat, big or small, strong or weak, thick or thin, all these factors contribute to the effectiveness of book design. Besides, the rhythm of lines, black or white, colors, symbols, and shapes are also key factors for the book design. Moreover, the book design is affected deeply by social, national, and history factors. Therefore, as we consider the beauty of form, we should study this issue from the social and history angle. By this way, we can motivate all factors concerning with the "form" in order to achieve an aesthetic book design. For example, although the Heart and Instruction that focuses on the effects of religious on people is dull, we can add more attractive factors, such as light colors, interesting illustrations, and other decorating elements, into the book under the teacher's direction. By this way, we can create an interesting and easy reading environment. It is easier for readers to be attracted by the book although its content is not so interesting.

In a word, no matter what it is the structure of form, or the combination of spots, lines, faces, colors, shapes, or the beauty of harmony and softness, or the beauty of changes, all these factors contribute to the book design. The "meaningful form" even includes the form of materials because the match of different materials can also reflect the beauty of rhythm.

\section{The book design and the book content is an organic unity.}

Book design should lay stress on its unity. According to this essential design idea, book design should serve for book content, aiming at reflecting book's general look. Therefore, designers should have a general idea in order to realize this 
goal as they get the book. In this aspect, it has two meanings as follow.

3.1 Designers should understand the theme and style of the book to certain degree.

Firstly, designers should be used to reading, holding a deep affection toward books. Secondly, they should make friends with writers and poets, understanding their ideas and thoughts, which may serve as preparations for their design. Thirdly, designers should keep on improving their cultural and aesthetic taste. The higher the aim is, the better they can do. Besides, book design must be the same inside and outside. In other words, it pursues the unification of content and configuration. Therefore, designers have to know the book content well, grasp its spirit, and understand the style of the writer and the characteristics of readers. By refining the essence of the book, designers can improve the general quality of the book by aesthetic form. In order to achieve the unification of content and configuration, designers should pay more attention on self-cultivation in many fields by reading. Absorb the essence and discard the worst. By this way, designers can improve their creative thinking abilities and design more excellent works.

3.2 Designers should understand the style and the theme of the book as much as possible.

The more the designers understand the book, the faster they complete the general design. And designers' knowledge structure, art culture, and aesthetic taste will affect the general composition. Since book design is a general work, designers must take materials and printing techniques into consideration. More important, designers should consider how to motivate all these factors to serve for the book's theme and content in order to achieve the unification of content and configuration. An excellent book design can inspire our aesthetic affection and desire for reading.

\section{References}

Deng, Zhonghe. (2004). Changeable Books. 23rd, June.

Jia, Kailan. (2004). The development of books’ graphic design. G. J. C Design Alliance. July.

Jiang, Deming. (2004). The books’ graphic design today in China. from Various Graphic Design for Books. July.

Liu, Jing. (2004). A discussion on books' exterior space and interior space. from Collection of Articles on China Contemporary Books' Graphic Design. Beijing: Juvenile \& Children Publishing House.

Qiu, Ling. (2004). Books' graphic design is the soul of books. Guangming Daily. July.

Yang, Yongde. (2004). An overlook on books’ graphic design. People’s Daily (Overseas Edition). 1st, July .

Zhuo, Xinping. (2003). Globalization and religious issue. Speeches in Universities (Series 2ed). Beijing: New World Press. Jan. 